\title{
Drapet på Svarstad - rettsmedisin anno 1753
}

\author{
I mai 1753 drepte en 25 år gammel norsk soldat en annen soldat med et kølleslag mot hodet uten tilsyne- \\ latende motiv. Under rettssaken påberopte den tiltalte seg utilregnelighet som følge av at han hadde drukket \\ brennevin som var aksidentelt forurenset med svimling (Lolium temulentum).
}

\section{Torgrim Sørnes}

torgrim.sornes@gmail.com

Gjerningsmannen ble først dødsdømt, og forgiftning med svimling ble avvist.

Etter flere behandlinger i rettsapparatet endte man opp med at offerets lege var skyld i dødsfallet fordi han ikke hadde trepanert sin pasient. Dette prokuratorknepet utløste en kongelig benådning for den dødsdømte.

\section{Slagsmålet}

25. mai 1753 skulle den 25 år gamle vervede soldaten Anders Hågensen marsjere fra Kongsvinger festning til tjeneste på Blaker skanse, som ligger i Sørum i Akershus ved Glommas venstre bredd.

Da Hågensen hadde kommet til Huseby gård, noen hundre meter sørøst for Blaker skanse, tok han inn for å forfriske seg med en pott $\varnothing 1$ - omtrent én liter. På vertshuset fant han tre av sine medsoldater, og det ble i tillegg bestilt og drukket to peler brennevin - en halv liter. Dette ble likt fordelt på de fire soldatene. Således fortifisert vandret Anders Hågensen med to av sine kamerater videre i retning Blaker skanse. Midtveis mellom Huseby og bestemmelsesstedet lå neste bondegård - Svarstad - her tok de inn igjen.

På Svarstad brøt det ut et masseslagsmål. Mot slutten av dette slo Anders Hågensen ned en annen soldat, Jakob Olsen, med en staur, to alen lang (noe under $130 \mathrm{~cm}$ ), tykk som en mannsarm «og med Qvister begroed». Da dette var gjort, rømte Hågensen til skogs.

Jakob Olsen ble lagt til sengs på Svarstad, og lege ble tilkalt (1).

\section{Sykeleie og død}

Denne legen var garnisonfeltskjæren på Blaker skanse, Hans Nielsen Hoff. Han burde være rik på praktisk erfaring - han hadde begynt som feltskjær allerede i 1727 (2). Tittelen «feltskjær» innebar at hans utdanning som kirurg var av rent praktisk natur som lærling eller svenn hos en eldre kirurg. Hadde han studert medisin ved Universitetet, ville hans tittel vært «physicus».

Han ankom Svarstad mellom kl. 19 og 20 om kvelden og fant pasienten i dyp søvn, med blod rennende ut av begge ører. Det var ikke mulig for Hoff å fastslå om pasientens «assouplissement» skyldtes hodeskade eller rus, så han valgte å avvente videre diagnostikk og behandling til pasienten hadde sovet rusen ut.

Neste dag kom Hoff tilbake og fant pasienten bevisst, klar og «bey vollkommener Vernunft». Jakob Olsen husket alt som hadde skjedd, og kunne fortelle legen at han hadde

\section{«Pasienten nappet ut strå fra madrassen og forsøkte å spise dem»}

fått to slag med køllen, et over venstre tinning og et støt i brystet. En nøyere legeundersøkelse avslørte intet urovekkende ut over at det fremdeles rant noe tynt blod ut av Jakob Olsens venstre øre.

Hoff rapporterte derfor til Olsens overordnede at pasienten nå var utenfor all fare. Dermed dukket også Anders Hågensen opp igjen fra sin flukt, meldte seg for kompaniet og lot seg arrestere.

Om morgenen den tredje dagen hadde situasjonen forandret seg dramatisk: Nå var pasienten ute av stand til å si noe som helst og lå ubevegelig i sengen. Hoff ble tilkalt på ny og oppfattet Olsen som så dårlig at han fikk ham transportert til sykebrakken på Blaker skanse. Der ble pasienten urolig, med hallusinasjoner, nappet ut strå fra madrassen og forsøkte å spise dem, han ville bite de som stelte ham, og slo rundt seg med så stor styrke at sykevokterne hadde sin fulle hyre med å holde ham i ro. Man fikk i ham noe øl og etter hvert også noe ølost.

Denne delirøse tilstanden varte ved til den femte dagen, da Olsen på ny klarnet opp og kunne kommunisere «bey guther Vernunft» - dette varte kun noen timer før han igjen var «in vorigen Raserey gefallen».

Den siste dagen lå Jakob Olsen så igjen helt stille. Han sa ikke et ord, før han til slutt døde åtte dager etter slagsmålet.

\section{Obduksjonen}

Den rettsmedisinske obduksjonen ble foretatt av feltskjær Hoff selv og hans overordnede, regimentfeltskjær Christian Gjerdrum (3). Obduksjon i drapssaker var påbudt i Kongelig forordning av 21. mai 1751. Det var påkrevet med ikke-medisinske vitner ved siden av obdusentene, foruten at den anklagede selv også skulle være til stede og bivåne autopsien. I dette tilfelle var de to legvitnene «zwey Officiers».

Gjerdrum var omtrent like gammel i tjenesten som sin kollega Hoff - han hadde begynt som bataljonfeltskjær i 1727 og hadde i 1753 vært regimentfeltskjær ved det 2. Akershusiske infanteriregiment i 15 år allerede.

Ved liksynet fant de først to små flekker $i$ huden over glutealmuskelen på venstre side. Da de klippet håret av liket, ble en ny blå flekk synlig - beskrevet som en «sugillation» - som strakk seg fra sutura coronalis bakover til bakhodet, mest tydelig på venstre side over tinningbeinet hvor det også var synlig en liten «tumor». Denne «tumoren» viste seg å inneholde koagulert blod.

De to obdusentene åpnet så hodeskallen og fant mer blod, delvis koagulert, delvis flytende, over pia mater på venstre side av sutura sagittalis. På selve kraniet var det ingen skade: «keine Fractur, Impression oder Fissura».

Obduksjonen stoppet der. Det ser ikke ut som om de to sakkyndige har tatt hjernen ut av hodeskallen eller lett etter andre dødsårsaker i resten av legemet.

Den intrakraniale blødningen ble angitt som dødsårsak, til tross for at mengden ble beskrevet som «wenig». Hoff og Gjerdrum mente også at pasienten kunne ha vært reddet ved en trepanering. Når Hoff ikke hadde utført det inngrepet, skyldtes det at han ikke hadde instrumenter til det - nevrokirurgien var nemlig sentralisert allerede den gang: Det var bare «die bey die Regimenten stehende Chirurgo» som skulle ha den slags instrumenter. Det var derfor regimentfeltskjær Gjerdrum som hadde trepanen, men han var ute på reise da Olsen lå syk.

De to konkluderte med at «den afdødes Skade i sig selv ikke var Dødelig, men at den per accidens er bleven dødelig, forme- 
delst Aabningen ikke strax i Begyndelsen skeede».

Habilitetsreglene var mindre strenge på 1700-tallet, rett og slett fordi antallet personer med utdanning var så lavt, og de fleste av dem var beslektet eller besvogret med hverandre. I dette tilfelle falt det uheldig ut for feltskjær Hoff at han både var behandlende lege og deretter rettsmedisiner - han rettet på et temmelig tynt grunnlag en anklagende pekefinger mot seg selv, en pekefinger som en mindre personlig engasjert lege kunne ha unngått.

\section{Svimling}

Det ble avholdt krigsrettssak på Kongsvinger festning 3. august 1753. Presidio (øverste dommer) var oberst Magnus Baron von Holck (4), kommandant på festningen.

Hågensen selv hevdet med styrke at han hadde vært utilregnelig under hele bataljen. Denne tilstanden skyldtes at det brennevinet de var blitt servert på Huseby, hadde vært forurenset med svimling (Lolium temulentum) - et kornlignende ugress som før 1900 var vanlig i Syd-Norge. Svimlingen vokste gjerne i kornåkrene og ble med på lasset når kornet ble høstet inn.

Svimling hadde tidligere mange anvendelser $-i$ sårbehandling spesielt: Man brukte den både mot lepra og kreft, da knust og blandet opp med pepperrot og salt (5). Inntatt per os ville planten bare gi hodepine og oppkast. Svimling - da under navnet «skjađak» - er nevnt allerede i Kongespeilet, men kun som et ugress som ødelegger kornhøsten (6). Flere av de farmakologiske forfatterne som var tilgjengelig i 1753, beskrev at symptomene ved forgiftning minnet om beruselse $i$ det at de ga skjelvinger, gangvansker, taleforstyrrelser og oppkast. Det latinske navnet på planten - temulentum - betyr likefrem «beruset» (7).

Under rettssaken sendte man forespørsler til brennevinsbrennere $i$ andre land om svimling. De svarte at svimling var noe de ofte hadde i kornet - det ble billigere sprit og dessuten sterkere rus. Men alle de fire soldatene hadde jo inntatt like mye av det samme brennevinet, så dermed kunne ikke svimlingen frifinne Hågensen uansett. Retten overså den liter med øl som Hågensen drakk først, og som de andre ikke rørte. Forgiftning av svimling har tradisjonelt vært mer assosiert med øl enn med brennevin, men dette var et poeng man ikke fikk med seg under sakens gang.

Anders Hågensen skaffet attester på at hans atferd under slagsmålet var ulikt hans vanlige væremåte - han ble ellers beskrevet som «en skikkelig og anstændig» person, og den mengden alkohol han hadde fortært, var etter forholdene beskjeden - «eine gantz massige portion», het det. Det ble også drøftet hvorvidt en person med «temperamente furieux» kunne reagere annerledes på rus enn en som var «schlafrich und indolent», men alle disse argumentene brast overfor det faktum at Hågensen rømte etter slagsmålet et tydelig bevis på at han var «sui mentis compos».

\section{«Den intrakraniale}

\section{blødningen ble angitt} som dødsårsak, til tross for at mengden ble beskrevet som 'wenig'»

\section{Den manglende trepanering}

Det er vanskelig å la være å føle sympati med vår kollega Hoff da han under obduksjonen måtte erklære at pasienten kunne ha vært reddet ved trepanering. Hoffs unnskyldning om at han manglet de nødvendige instrumentene til trepanering ble blåst av i retten. Han skulle absolutt ha skaffet dem hos sin kollega Gjerdrum, eller «i saa høist nødvendigt Tilfælde fra Christiania». Det ble overhodet ikke problematisert at det faktisk var myndighetene selv som hadde skapt denne situasjonen ved sitt sentraliseringsvedtak. Ingen nevnte heller noe om hva slags trening Hoff skulle ha fått $i$ bruken av et instrument han ikke fikk lov å ha i sitt armamentarium.

Trepanering i seg selv var ikke noen raritet på 1700-tallet. Mortaliteten var høy selv i de mest kyndige hender, og La Charrière skrev i år 1700 at «selv ikke de mest berømte leger våger å utføre inngrepet, da de frykter at de ikke finner noe, og derfor vil bli ansett for dumdristige» (8). Samme år som Jakob Olsen døde på Blaker skanse, ble det foretatt en trepanering i Magdeburg på en pasient med lignende symptomer, med et katastrofalt resultat (9). Selv på et stort sykehus som Hôtel Dieu i Paris var mortaliteten opp mot $100 \%(10)$.

\section{Dom og appell}

Oberst Holck dømte 3. august 1753 Anders Hågensen til døden ved halshugging. Etter å ha gitt en klaps på hånden til feltskjær Hoff og i en bisetning avskrevet svimlingens rolle påkalte Holck lovens § 6-6-1 om forsettlig drap - «homicidum simplex».

Saken ble deretter rutinemessig sendt inn til Carl von der Schulenburg (11), den norske generalauditøren, som skulle forberede en appell til Kongen om hvordan denne dommen skulle forstås, og om en form for benådning kunne finne sted. Han sparket ballen videre 29. september til sin slektning Werner von der Schulenburg (12), overkrigssekretæren i København.

De to ble enige om å søke sakkyndig hjelp. Schulenburg hadde åpenbart ingen tiltro til de lokale kreftene og valgte å henvende seg til det juridiske fakultetet i Göttingen, som fikk henvendelsen høsten 1753. Kunne de lærde herrer uttale noe fornuftig om hvorvidt menig Hågensen skulle halshugges på Galgebakken i Kongsvinger?

I januar 1754 ankom så den lærde betenkningen fra «Ordinarius Senior und sämtliche assessores der Juristen Facultät». Man gikk skrittvis frem:

Hva beruselsen angikk, var rus i seg selv «ein Laster» og ville aldri kunne tjene til unnskyldning for en forbryter. At Anders Hågensen var bevisstløs som følge av fyll var verken bevist eller spesielt sannsynlig.

Svimlingen derimot (som de rettslærde i Göttingen kalte for «Trespe») var noe mer interessant. Dette stoffet hadde den egenskapen at den kunne gjøre folk «rasend oder aberwitzig». På den annen side hadde morderen drukket like mye brennevin som de andre, og var ifølge vitnene heller ikke fullere enn dem.

Til gjengjeld konsentrerte juristene i Göttingen seg om Hågensens opphisselse under slagsmålet. Man valgte en tolkning av begivenhetene hvor det slaget Hågensen hadde gitt Olsen, ikke var blitt utført med hensikt å drepe, men under kampens hete - noe lignende det vi i dag ville kalt «legemsfornærmelse med døden til følge», et begrep som formelt ikke eksisterte i norsk rett anno 1753.

Da Olsen døde, skyldtes dette derfor ikke Hågensens overlegg eller forsett, men derimot «der schlechten Cur der Wunde», og man erklærte likefrem at den skyldige like mye var «der Chirurgus» som Hågensen. Feltskjær Hoff hadde jo to dager etter slaget erklært at pasienten var utenfor all fare, han hadde ikke gjort nok for å skaffe seg de nødvendige instrumentene, og han hadde heller ikke forsøkt noen annen fornuftig måte å redde Olsens liv på.

Slaget hadde ikke forårsaket døden hvis ikke «Jakob Olsen per accidens var falt 
i hendene på en kirurg som mot regler og prinsipper i den kirurgiske kunst» ikke ga pasienten korrekt omsorg.

Med rene ord beklaget juristene seg over at «der Geschlagenen in die Hände eines so elender Artzes gerathen». På dette grunnlag anbefalte man at Hågensen ble benådet for dødsdommen og sendt i fengsel noen år.

Hans Majestet Kong Frederik 5. aksepterte 20. mars 1754 disse synspunktene og befalte at Anders Hågensen skulle arbeide i jern på Kongsvinger festning i syv år, og 11. april vandret gjerningsmannen inn bak murene med solide fangejern rundt beina.

\section{Epilog}

Christian Gjerdrum døde allerede i 1756 mens Hågensen fremdeles gikk i sine jern på festningen.

Hans Hoff fortsatte i sin stilling som garnisonfeltskjær frem til 1758 da også han døde. Man kan merke seg at når Gjerdrums stilling ble ledig i 1756 vanket det ikke noe opprykk for Hoff, men det ble tvert imot ansatt en yngre mann, Ditlev Rist, med mye kortere ansiennitet (13).

Saken demonstrerer en del underlige for- hold: Man overså fullstendig det forurensede ølet, Jakob Olsens hodeskade med blødning ut av øret og den kongelige bestemmelsen om at bare regimentfeltskjærene skulle ha trepaner. Juristene mente selv å kunne bedømme både legens handlinger og sakens toksikologiske aspekter uten å konferere med medisinsk sakkyndige, og omtalte feltskjær Hoff i direkte injurierende vendinger.

Samtidig ser det fra dokumentene ut som om myndighetene åpenbart ønsket å benåde Hågensen fra dødsstraffen. For å oppnå dette formålet valgte man å legge skylden på offerets lege i stedet.

\section{Torgrim Sørnes (f. 1956)}

er spesialist i fødselshjelp og kvinnesykdommer. Han har utgitt tre bøker om eldre norsk rettshistorie.

Forfatter har fylt ut ICMJE-skjemaet og oppgir ingen interessekonflikter.

Litteratur

1. Riksarkivet. Generalauditørens justisprotokoll

1753. http://arkivverket.no/URN: rg_read/38989/3/ (18.2.2016)
2. Ovenstad 0. Militærbiografier - den norske hærs officerer 1628-1814, bind I. Oslo: Norsk slektshistorisk forening, 1948: 472

3. Ovenstad O. Militærbiografier - den norske hærs officerer 1628-1814, bind I. Oslo: Norsk slektshistorisk forening, 1948: 341.

4. Ovenstad O. Militærbiografier - den norske hærs officerer 1628-1814, bind I. Oslo: Norsk slektshistorisk forening, 1948: 477.

5. Reichborn-Kjennerud I. Den gamle urtegård. Lægeurter fra middelalderen. Sarpsborg: Borgarsyssel museum, 1930.

6. Kongespeilet. Oslo: Aschehoug, 1947: 75

7. Johanssen J, Nygaard M, Schreiner E. Latinsk ordbok. 4. utg. Oslo: Cappelen, 1987

8. de La Charrière J. Tractatus Operationum Chirurgicarum oder Abhandlung chirurgischer HandGriffen. Frankfurt: GH Oerling, 1700.

9. Arnott R, Finger S, Smith CUM. red. Trepanation. Lisse: Swets \& Zeitlinger, 2005: 273

10. Dionis P. Chirurgie. Augsburg: 1734

11. Ovenstad O. Militærbiografier - den norske hærs officerer 1628-1814, bind II. Oslo: Norsk slektshistorisk forening. 1948: 378.

12. Bricks CF. Dansk biografisk lexikon, bind XV. København: Gyldendalske Boghandels Forlag, 1901: 323.

13. Ovenstad O. Militærbiografier - den norske hærs officerer 1628-1814, bind II. Oslo: Norsk slektshistorisk forening, 1948: 309.

Mottatt 2.8. 2015, første revisjon innsendt 4.10.2015, godkjent 18.2. 2016. Redaktør: Inge Rasmus Groote. 